\title{
GIS Maps as Powerful Curriculum Artefacts
}

\author{
Mary Fargher * \\ ${ }^{a}$ University College London, Institute of Education, London,WC1HOAL, m.fargher@ucl.ac.uk \\ * Corresponding author
}

\begin{abstract}
Maps have always been central to high quality geography education. Recent developments in web GIS have opened up new potential for teachers using GIS maps as powerful curriculum artefacts. Curriculum artefacts are resources that have signature meaning for teaching and learning. This paper argues that the use of GIS maps as curriculum artefacts can significantly enhance geography teaching and learning in schools. To illustrate this line of argument, a GIS curriculum artefact constructed in ESRI ArcGIS Online is critically evaluated using Maude's typology of powerful geography knowledge as an analytical framework. The analysis identifies a number of educational benefits of using GIS maps as curriculum artefacts in school geography via a GeoCapabilities approach. The paper concludes with recommendations for the future geography curriculum development with GIS map artefacts in schools.
\end{abstract}

Keywords: GIS map, curriculum artefact, powerful disciplinary knowledge (PDK), geography education

\section{Introduction}

This paper makes a case for the use of GIS maps in constructing curriculum artefacts in school geography. The discussion begins with a review of the historical contribution of GIS to spatial thinking and enquiry-based learning in geography. The more recent developments with GIS including the use of smart mapping, open source data and mobile applications are then discussed.

A case is made for a geography knowledge-led approach to their use of GIS maps in the classroom. The underpinnings of a capabilities approach to education are then introduced, including: powerful disciplinary knowledge (Young, 2008), a Future 3 curriculum (Young, Lambert, Roberts and Roberts, 2014), curriculum making (Lambert and Morgan, 2010) and curriculum artefacts (Biddulph, Lambert and Balderstone 2015).

A GIS map curriculum built in ESRI ArcGIS Online according to GeoCapabilities principles is then presented. The artefact is critically analysed using Maude's typology of powerful geography knowledge as a framework (Maude, 2016).

The paper then draws conclusions from this analysis and makes recommendations for the future use of GIS map curriculum artefacts in geography education.

\section{GIS in Geography Education}

Evidence reflecting the educational benefits of using GIS is wide-ranging. GIS in geography education has a long history of being used to develop spatial thinking (National Research Council, 2008), promote enquirybased learning (Fargher, 2017), supplement geography fieldwork (Favier and Van der Schee, 2012) and enhance student's visualisation of geographical phenomena (Lei, Kao, Lin and Sun, 2009; Fargher, 2018).

When used to its full potential GIS can provide comprehensive learning environments with proven potential for enquiry based learning about geographical problems, issues and events of real world relevance (Fargher and Rayner, 2012). GIS enquiry usually focuses on five types of questions as shown in Table 1 (ESRI, 2003).

\begin{tabular}{|l|l|l|}
\hline Step & What to Do & $\begin{array}{l}\text { Type of } \\
\text { Knowledge } \\
\text { Construction }\end{array}$ \\
\hline $\begin{array}{l}\text { Ask a } \\
\text { geographical } \\
\text { question }\end{array}$ & $\begin{array}{l}\text { Ask questions about } \\
\text { the world around you }\end{array}$ & Enquiry \\
\hline $\begin{array}{l}\text { Acquire } \\
\text { geographical data }\end{array}$ & $\begin{array}{l}\text { Identify data and } \\
\text { information that you } \\
\text { need to answer your } \\
\text { questions }\end{array}$ & Inventory \\
\hline $\begin{array}{l}\text { Explore } \\
\text { geographical data }\end{array}$ & $\begin{array}{l}\text { Turn the data into } \\
\text { maps, tables, graphs } \\
\text { and look for patterns } \\
\text { and relationships }\end{array}$ & $\begin{array}{l}\text { Spatial } \\
\text { processing } \\
\text { and analysis }\end{array}$ \\
\hline $\begin{array}{l}\text { Analyse } \\
\text { geographical } \\
\text { information }\end{array}$ & $\begin{array}{l}\text { Test a hypothesis, } \\
\text { carry out map, } \\
\text { statistical, written } \\
\text { analysis using } \\
\text { evidence }\end{array}$ & $\begin{array}{l}\text { Spatial } \\
\text { Analysis, } \\
\text { Modelling, } \\
\text { Decision } \\
\text { Making }\end{array}$ \\
\hline
\end{tabular}

Table 1. Steps in Enquiry in GIS (After ESRI, 2003)

Enquiry is acknowledged as a key feature of high quality geography education in several countries (Roberts, 2013). GIS has a strong track record of moving geographical enquiry towards a deeper type of questioning using geographical evidence to enable pupils to interrogate 'the whys of where' (Kerski, 2003).

\subsection{Web GIS}

For school geography, the move of GIS to the web has largely removed previous obstacles of complex GIS software and limited access to data (Baker, 2015). Webbased mapping platforms such as ESRI ArcGIS Online and QGIS Cloud are now more commonplace in schools. In principle, web mapping is more intuitive than earlier forms of GIS with interfaces which do not require as much expert GIS knowledge to use and can be accessed through a web browser. Three developments for geography education are most significant: intuitive interactive mapping, open source data and mobile applications. 


\subsubsection{Intuitive Interactive Mapping}

Intuitive interactive mapping such as the smart mapping capability built into ESRI ArcGIS Online is designed to enable expert and novice users to produce professional quality maps more quickly and more easily than in the past. Offering automatic 'smart' defaults, smart maps offer users a 'best fit' for their choice of map, analysis or presentation of data. For many teachers, where these applications are well-designed, this has been a significant step forward as the need to learn more complex GIS procedures is beginning to be superseded.

\subsubsection{Open Source Data}

The impact of open source data on the use of geospatial applications in schools has been significant. Specialised applications such as EDINA's DigiMap Open Stream provide free web map services (WMS) to schools, making geospatial data easier to use and process than it has been in the past. One of the most significant developments, the creation of Open Street Map (2006) has been highly influential in the support, development, growth and distribution of free geospatial data that anyone can access, use and share.

\subsubsection{Mobile Applications}

The development of more flexible cloud-based mobile applications can allow teachers and their pupils to collect their data in a systematic way through intuitive interactive mapping via applications such as ESRI's editable feature services (EFS) and allow teachers to assign their pupils to collect data individually or collaboratively through any smart-enabled mobile devices. For example, ESRI's EFS enables teachers to design fieldwork with mobile applications such as Survey 123. So that they can control how, where and what their students collect whilst out in the field, eliminating much of the previous complexity and technological problems associated with using GPS receivers. Data can be collected quickly and efficiently, stored in the cloud and used seamlessly once back in the classroom.

This paper thus far has discussed the main advantages of using GIS in geography education and the ways in which innovations related web GIS are having impact on the geography classroom. The next section introduces the GeoCapabilities approach to geography education and makes a case for teachers using this approach to enhance their use of GIS and the quality of geography education in schools.

\subsection{GeoCapabilities}

The GeoCapabilities approach to geography education has firm roots in the field of human capabilities development originating from the work of Amartya Sen and Martha Nussbaum on welfare economics and social justice (Nussbaum and Sen, 1993). In their treatise, Nussbaum and Sen encourage deep consideration of the role of education in shaping how an individual thinks and acts, their autonomy and ultimately, their potential to thrive and contribute positively to society. The GeoCapabilities approach also argues that the expansion of specific human capabilities is followed by human empowerment to think and act in ways that fulfil one's future prospects. Fundamental to GeoCapabilities thinking is an emphasis on a progressive, subject-led approach to teaching school geography particularly through the development of powerful disciplinary knowledge (Lambert, Solem and Tani, 2015).

\subsubsection{Powerful Disciplinary Knowledge (PDK)}

Powerful disciplinary knowledge originates from the work of Michael Young (2008) who argues that school subject knowledge can only be powerful when it empowers young people to think in ways beyond their direct experience. Young maintains that all young people regardless of background should be eligible to access this kind of specialist knowledge. It can be argued that young people who have access to powerful disciplinary knowledge and the intellectual capacities they may develop with it are afforded a crucial element of their true human potential. An argument for developing powerful disciplinary knowledge fundamentally implies that subject specialist teachers provide the best prospects for their pupils to be given access to PDK which can be used to help them to think in distinctive, disciplined ways.

It is imperative to be clear on how powerful disciplinary knowledge can be recognised. Lambert (2014), discussing geography education specifically, argues that it is important that powerful knowledge is 'made' in accordance with a defined rigour and attention to scholarly detail. Powerful knowledge is therefore, Lambert argues, evidence based, abstract and conceptual and is part of a broader established system of disciplinary thought. It is also dynamic and evolving but imminently reliable. It is testable and should be open to challenge. Powerful knowledge may also be counter-intuitive and exist outside the direct experience of the teacher and the learner. In these ways, according to a GeoCapabilities way of thinking, powerful geographical knowledge has a key role to play in an individual's education (Solem, Lambert and Tani, 2013).

Maude has contributed further to the powerful knowledge debate in geography education by identifying powerful geographical knowledge by the way it is produced and considering the intellectual power it gives to those who have it (Maude, 2016). Table 2 illustrates a typology of geography's powerful knowledge according to Maude.

\begin{tabular}{|c|c|c|}
\hline Type & & Characteristic \\
\hline 1. & $\begin{array}{l}\text { Knowledge that provides students } \\
\text { with 'new ways of thinking about } \\
\text { the world.' }\end{array}$ & $\begin{array}{l}\text { Using 'big ideas' such as: } \bullet \text { Place } \\
\text { - Space } \bullet \text { Environment } \bullet \\
\text { Interconnection } \\
\text { These are meta-concepts that are } \\
\text { distinguished from substantive } \\
\text { concepts, like 'city' or 'climate'. }\end{array}$ \\
\hline 2. & $\begin{array}{l}\text { Knowledge that provides students } \\
\text { with powerful ways of analysing, } \\
\text { explaining and understanding. }\end{array}$ & $\begin{array}{ll}\text { Using ideas to: } \\
\text { - } & \text { Analyse e.g., place; spatial } \\
& \text { distribution } \\
\text { - } & \text { Explain e.g., hierarchy; } \\
& \text { agglomeration } \\
\text { - } & \text { Generalise e.g., models } \\
& \text { (push-pull models of } \\
\text { migration; demographic } \\
\text { transition) }\end{array}$ \\
\hline
\end{tabular}




\begin{tabular}{|c|c|c|}
\hline 3. & $\begin{array}{l}\text { Knowledge that gives students } \\
\text { some power over their own } \\
\text { knowledge. }\end{array}$ & $\begin{array}{l}\text { To do this, students need to know } \\
\text { something about the ways } \\
\text { knowledge has been, and continues } \\
\text { to be developed and tested in the } \\
\text { discipline. This is about having an } \\
\text { answer to the question: 'how do } \\
\text { you know?' This is an } \\
\text { underdeveloped area of } \\
\text { geographical education, but is a } \\
\text { crucial aspect of 'epistemic quality' } \\
\text { (Hudson, 2016). }\end{array}$ \\
\hline 4. & $\begin{array}{l}\text { Knowledge that enables young } \\
\text { people to follow and participate in } \\
\text { debates on significant local, } \\
\text { national and global issues. }\end{array}$ & $\begin{array}{l}\text { School geography has a good } \\
\text { record in teaching this knowledge, } \\
\text { partly because it combines the } \\
\text { natural and social sciences, and } \\
\text { the humanities. It also examines } \\
\text { significant 'nexus' issues such as: } \\
\text { food, water and energy security; } \\
\text { climate change; development. }\end{array}$ \\
\hline & Knowledge of the World & $\begin{array}{l}\text { This takes students beyond their } \\
\text { own experience- - the world's } \\
\text { diversity of environments, } \\
\text { cultures societies and economies. } \\
\text { In a sense, this knowledge is } \\
\text { closest to how geography is } \\
\text { perceived in the popular } \\
\text { imagination. It contributes } \\
\text { strongly to a student's 'general } \\
\text { knowledge'. }\end{array}$ \\
\hline
\end{tabular}

Table 2. A typology of geography's powerful knowledge (Maude, 2016)

\subsubsection{Curriculum Futures}

Another key way in which a GeoCapabilities approach to teaching geography is distinctive in promoting a knowledge-led curriculum is through analysis of a 'curriculum futures' framework. This involves careful consideration of the ways in which the curriculum is 'made' in schools. This can be categorised as a Future 1, Future 2 or Future 3 approach to the curriculum (Young and Muller, 2010). Future 1 (F1) is subject 'delivery' with the curriculum seen as a 'given'. In an F1 scenario, the curriculum is arranged within traditional subjects with a stable body of core knowledge. This therefore is undersocialised knowledge.

In an F2 scenario the focus is on skills, competences and 'learning to learn'. This approach considers traditional subject divisions as 'arbitrary'. Instead, integrated themes and issues are preferred. This is therefore experiential and over-socialised knowledge.

In a Future 3 (F3) scenario, subjects are either 'given' or 'arbitrary'. Knowledge development is instead led by epistemic rules of recognised subject specialist communities to provide ways to understand the world and take pupils beyond their everyday experience (Young, Lambert, Roberts and Roberts, 2014).

GeoCapabilities adopts an F3 approach and is therefore underpinned by the belief that knowledge development in schools should be led by subject specialists who are best placed to provide young people with the highest quality geography education. Geography is particularly relevant to a 21 st century education where pupils should be given the best intellectual opportunities to become knowledgeable about complex issues such as humaninduced climate change, population pressure and complex geo-political shifts to name but a few. The discipline of geography provides meta-concepts or 'big ideas' such as place, space and interconnection from which the specialist teacher can draw to prioritise and underpin how they shape the curriculum to engage pupils in thinking geographically in powerful ways (Solem, Lambert and Tani, 2014). A Future 3 GeoCapabilities approach to geography education fully supports the idea that teachers engage in making a geography curriculum which is knowledge-led and enables young people to think deeply with their geography to make informed and decisions based on robust disciplinary knowledge in an increasingly interdependent and globalised world (Lambert, 2014). A crucial part of this approach is the process of curriculum making.

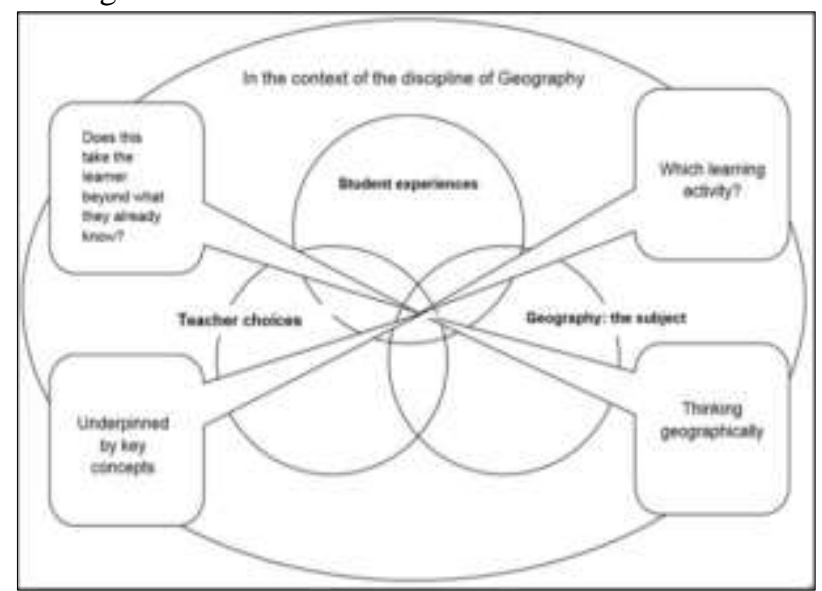

Figure 1. The curriculum making model (Lambert and Morgan (2010)

\subsubsection{Curriculum Making}

Curriculum making lies at the heart of teachers adopting a GeoCapabilities approach. Figure 1 illustrates the main components of the curriculum making model (Lambert and Morgan, 2010). The model brings together geography the subject, teacher choices and student experiences. The model is planned to engage teachers in deep thinking about four complementary and interconnected functions of their curriculum work:

- Supporting the curriculum with geography's key concepts;

- $\quad$ Taking a learner beyond what they already know;

- Choosing learning activities which reflect curricular aims that are modified to student needs and experiences;

geographically.

Engaging young people in thinking

\subsubsection{Curriculum Artefacts}

An important approach to making the curriculum is through the formation of a 'curriculum artefact'. A curriculum artefact is considered as the 'key' to a series of lessons on a given topic. This can take the form of a particular resource such as a map, a series of photographs, a set of numerical data, a text or a combination of these. Curriculum artefacts are often multi-layered (Biddulph, Lambert and Balderstone, 2015).

The next section explores how a geography subject-led approach, web GIS tools and enquiry learning can be 
used to construct a geography curriculum artefact based on the 2004 Indian Ocean earthquake and tsunami (Fargher, 2018).

\section{A Web GIS geography artefact: The 2004 South Asia earthquake and tsunami}

This section draws on Maude's typology (Table 2) to discuss how a GIS map artefact developed in ESRI ArcGIS Online was used to support construction of powerful geography knowledge about the 2004 Indian Ocean earthquake and tsunami (Fargher, 2018). The 2004 South Asia earthquake and tsunami was a highly complex tectonic event. The December 26, 2004 occurred due to a rupturing of the subduction zone that lies between the Indian plate and the Burma microplate. The vertical offsetting of the ocean floor by 7 to 10 meters during displaced huge volumes of water which resulted in a number of destructive tsunami around the fringes of the Indian Ocean (Saatcioglu, Ghobarah and Nistor, 2005).

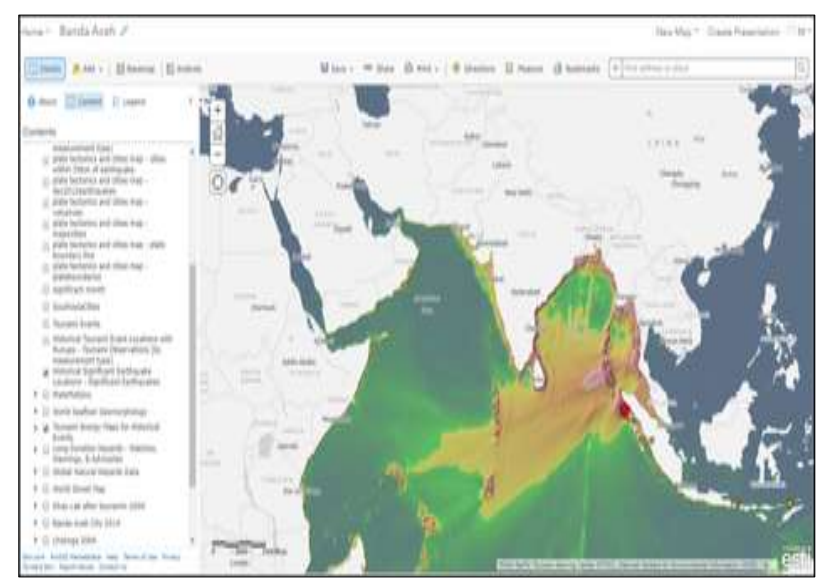

Figure 2. The artefact base map (Fargher, 2018)

The artefact base map (Figure 2) contains earthquake data on date and time, depth, Richter scale magnitude, Mercalli intensity and duration. Tectonic and human impact summaries are also included as map bookmarks. A range of 'before' and 'after' photographs and satellite images of specific locations affected are also included.

\subsection{Using interconnection to explain the causes of the 2004 Indian Ocean earthquake and tsunami (Type 2 Powerful Knowledge).}

Interconnection is essential to unlocking geography's power to explain causes and effects (Maude, 2016). GIS has always been used as a system to make connections by mapping attribute data at specific locations. This paper argues that using GIS to connect data sets on the 2004 Indian Ocean earthquake and tsunami can empower students to map a number of significant causal relationships (Fargher, 2018). For example, Figure 3 links local data at the earthquake epicentre with regional data on plate boundary movements. The map also contains a range of data from which students can identify the information required to ask a number of challenging geographical questions (Step 1 in the Steps in GIS Enquiry Process shown in Table 1) about: plate boundaries

The relative location of earthquakes to

- $\quad$ The magnitude and intensity of earthquakes in relation to the build-up of tectonic pressure as the Indian plate subducted under the Burma plate

- $\quad$ The release of pressure on the strike-slip fault running along the seabed as it split north south from the line of subduction north to the main earthquake epicentre in the south

- $\quad$ The subsequent shifting of the ocean eastwest through fault failure

- $\quad$ The generation and direction of travel of the tsunamis

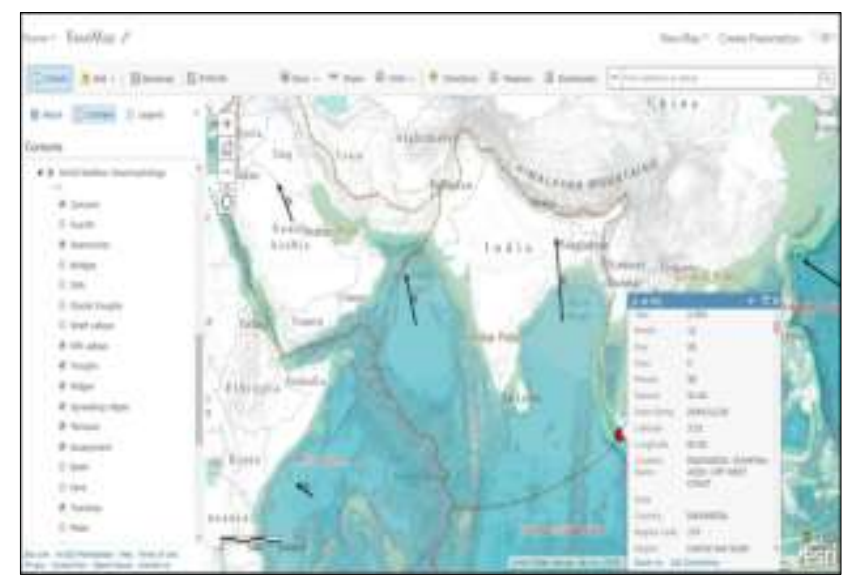

Figure 3. Exploring the causes of the 2004 Indian Ocean earthquake (Fargher, 2018)

Figure 4 shows a tectonic elevation profile drawn to display the geomorphology of the Indian Ocean floor. This tool can be used by students to acquire further geographical data (Step 2 in the Steps in GIS Enquiry Process). Students could investigate the ocean floor more closely to draw their profiles of their own choice in different locations to explore geomorphological and tectonic differences. Students could display and explain the shape and position of tectonic features such as trenches associated with converging plates and ridges associated with diverging plates (Fargher, 2018).

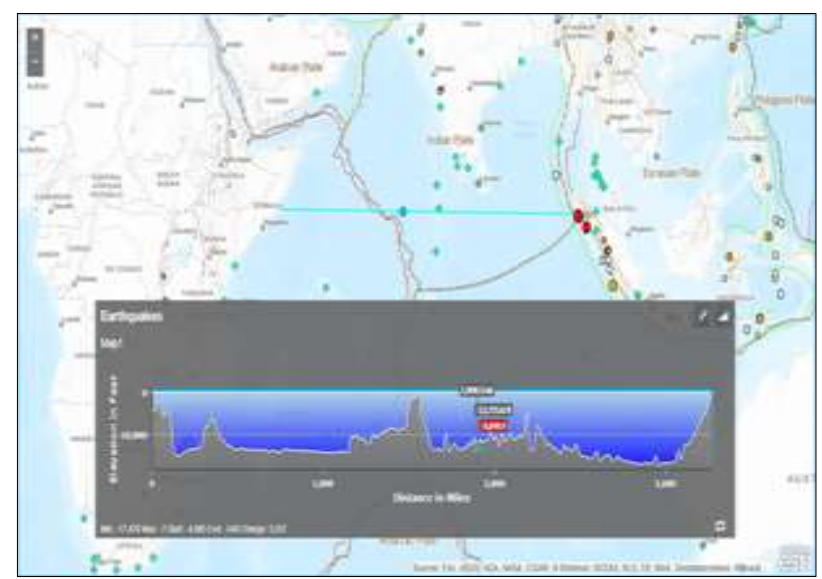

Figure 4. Exploring the shape of the ocean floor (Fargher, 2018) 
3.2. Using space and place to analyse regional and local variations in tsunami impacts (Type 2 Powerful Knowledge)

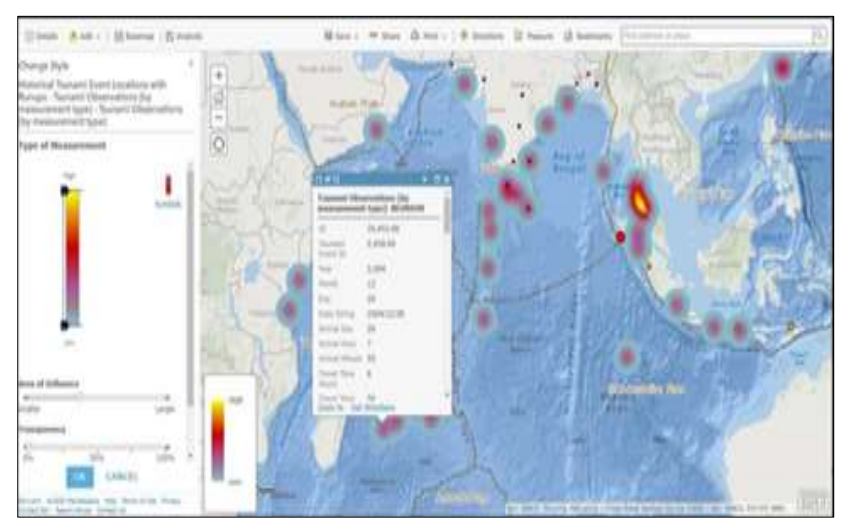

Figure 5. Exploring tsunami hotspots (Fargher, 2018)

Figure 5 shows a hotspot map constructed to analyse spatial variations in tsunami impacts. Students could use the map to ask further geographical questions (Step 1 in the Steps in the GIS Enquiry Process) about:

- The east-west spread of the tsunamis radiating from the north-south tectonic fault

- Variations in tsunami arrival times (e.g., 15 min Sumatra/7 h Somalia)

- The role of distance (e.g., nearby Bangladesh experienced fewer casualties/distant Somalia experienced more casualties)

- Unexpected high impacts in distant places (e.g., Kerala, India despite an intervening landmass, Sri Lanka west coast via headland wave defraction)

- $\quad$ Tsunami lag time in Thailand despite its proximity, as waves slowed down in the shallower Andaman Sea

- $\quad$ Varying Impacts on the region as a whole as communities surprised by waves due to no tsunami warning systems (Fargher, 2018).

The map contains a range of data from which students could acquire and explore the information to answer questions on each of the spatial variations described above which illustrate steps 2 and 3 in the Steps in the GIS Enquiry Process (Fargher, 2018).

\subsection{Using place to analyse variations in tsunami} impacts at a local scale (Type 2 Powerful Knowledge)

Places can be considered as natural centres for the study of complex relationships between geographical processes and phenomena (Rediscovering Geography Committee, 1997, Maude, 2016). Figure 6 shows a web GIS map to analyse impacts of the tsunami at a local scale. Students could use tsunami run up, arrival, height, impact data, aerial imagery and photographs of specific locations to connect specific geographical variables with the extent of tsunami impacts.

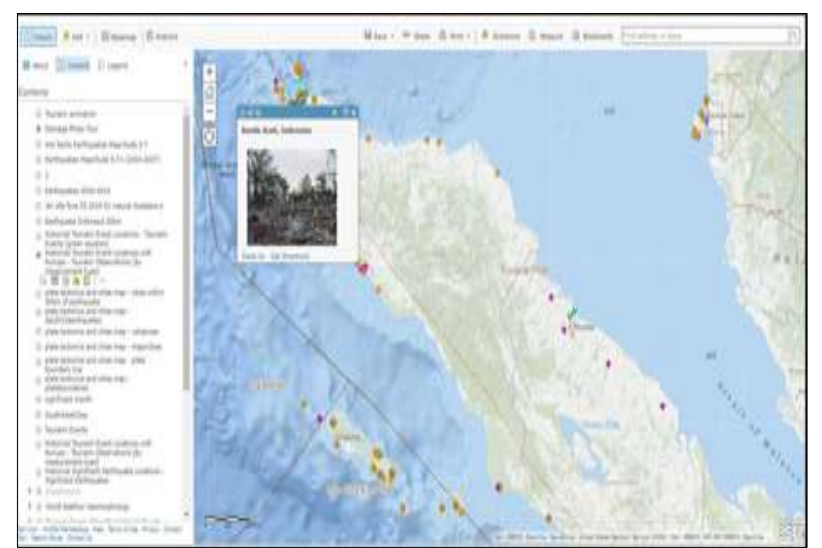

Figure 6. Aceh and tsunami impacts at a local scale (Fargher, 2018)

For example in studying impacts in Aceh, Indonesia, students could use Figure 6 to ask questions of the data (Step 1 in GIS Enquiry) about:

- $\quad$ The contrasting inundation of tsunami on the west (less affected) side of the Banda Aceh coast as opposed to the east sea side (more affected)

- $\quad$ Coastal villages on the low-lying islands of Weh, Breueh and Nasi just north of the mainland that were completely destroyed

- $\quad$ Lhoknga, the first major town to be hit by tsunami which received waves as high as 30 metres and was totally destroyed

- Meulobah, where the inland inundation reached over 5 kilometres (Fargher, 2018).

\subsection{Using place, space and interconnection to make} generalisations (Types 2, 3 and 5 Powerful Knowledge)

As this paper has shown, where GIS applications are suitably accessible for teachers and their students contemporary web GIS is well-suited to the creation of a geography curriculum artefact such as the South Asia earthquake and tsunami artefact described here. In the example, a GIS enquiry-based learning (EBL) approach, the web GIS maps and the tools contained within them can be used in conjunction with geography's metaconcepts of place, space and interconnection to explain and analyse a range of key physical and human elements of the 2004 Indian Ocean Tsunami (Type 2 knowledge). The complexities of nexus events such as the 2004 these also lend themselves to inventive teachers adopting enquiry approaches involving student's specific use of a range of geographical concepts, ideas and themes within the event to generalise about patterns (Type 2 knowledge). Students could access a range of information about human and physical factors involved and decide for themselves which variables to explore, map and analyse further (Fargher, 2018). 


\section{Conclusions}

New web GIS tools are of considerable significance for geography education not only in terms of their applications for mapping, analysing and explaining geographical patterns. The removal of some of the most significant historical barriers to GIS use in schools regarding cost, complexity and access has been a real watershed for those teachers now incorporating the use of web GIS into their classrooms.

However, this paper has also argued that the successful implementation of these kinds of innovations is only really part of the story in ensuring that web GIS tools achieve their full potential for geography education.

Future use of web GIS tools to enhance geography education needs to embrace not only the technological innovations and those continuing challenges that are still associated with web GIS but also the creation of powerful curriculum artefacts through a GeoCapabilities approach. This paper has demonstrated how leading the use of Web GIS maps with expert geography subject knowledge and EBL can build powerful web GIS artefacts designed to engage students in geographical thinking that is fundamentally underpinned by the subject's key concepts. This paper has also stressed the central role of specialist geography knowledge as well as GIS knowledge in teacher's work as curriculum makers. It should be noted that a GeoCapabilities approach to using web GIS does imply a distinct change in approach for teacher educators training new and continuing teachers to use GIS. The use of geospatial information in school geography has entered a new era, one in which the promise of high quality mapping, spatial analysis and geovisualisation to support geographical learning via web GIS is more achievable than it has been before. However, teaching geography teachers GIS skills will not be enough to achieve this potential fully, even in this era intuitive interactive mapping, more available open source data and potentially easier to use smart mobile applications. As Doreen Massey (2014) stated in 'Taking on the World', meaningful teaching and learning about the planet's many pressing contemporary issues such as climate change, geopolitical shifts and patterns of economic uncertainty have never been so significant. For young people this should include making the very most of teaching through the interactive learning environments that Web GIS now has to offer but this should be through geography's key concepts, the significance of geographical context and the specificity and the interconnectedness of places (Fargher, 2018).

Author Contributions: Mary Fargher is the sole author. Conflicts of Interest: The author declares no conflicts of interest.

\section{References}

Baker, T.R. Web GIS in Education. In Geospatial Technologies and Geography Education in a Changing World; Muñiz Solari, O., Demirci, A., van der Schee, J.A., Eds.; Springer: Dordrecht, The Netherlands, 2015; 105-115.
Biddulph, M; Lambert, D; Balderstone, D. Learning to Teach Geography in the Secondary School: A Companion to School Experience; Routledge: Abingdon, UK, 2015.

ESRI Survey 123 for ArcGIS https://survey123.arcgis.com/ (accessed on 04 April, 2019).

Fargher, M., Rayner, D. United Kingdom: Realizing the potential for GIS in the school geography curriculum. International perspectives on teaching and learning with GIS in secondary schools. Springer US.2012.299-304.

Fargher, M. GIS and the Power of Geographical Thinking. In C. Brooks, G. Butt, M. Fargher (Eds.), The Power of Geographical Thinking. Springer 2017.151-164. Fargher, M. WebGIS for Geography Education: Towards a GeoCapabilities Approach. ISPRS Int. J. Geo-Inf. 2018, 7, 111.

Favier, T.T.; Van der Schee, J.A. Exploring the characteristics of an Optimal Design for Inquiry-based Geography Education with Geographic Information Systems. Computers \& Education, 58(1). 2012.666-677.

GeoCapabilities. http://www.geocapabilities.org/trainingmaterials/module-2-curriculum-making-by-teachers/intopractice/ (accessed on 04 April 2019).

Kerski, J.J.The Implementation and Effectiveness of Geographic Information Systems Technology and Methods in Secondary Education. Journal of Geography, 102, (3) 2003, 128-137.

Lambert, D.; Morgan, J. Teaching Geography 11-18: A Conceptual Approach; Open University Press: London, UK, 2010.

Lambert, D. Curriculum Thinking, 'Capabilities' and the Place of Geographical Knowledge in Schools. J. Jpn. Educ. Res. Assoc. Soc. Stud. 2014, 81, 1-11.

Lambert, D.; Biddulph, M. The dialogic space offered by curriculum-making in the process of learning to teach, and the creation of a progressive knowledge-led curriculum. Asia-Pac. J. Teach. Educ. 2015, 43, 210-224. Lambert, D.; Solem, M.; Tani, S. Achieving human potential through geography education: A capabilities approach to curriculum making in schools. Ann. Assoc. Am. Geogr. 2015, 105, 723-735.

Lei, P.L., Kao, G.Y.M., Lin, S.S, Sun, C.T. Impacts of geographical knowledge, spatial ability and environmental cognition on image searches supported by GIS software. Computers in Human Behavior, 25(6). 2009, 1270-1279.

Massey, D. Taking on the World. Geography 2014, 99, 36-39.

Maude, A. What might Powerful Knowledge look like? Geography 2016, 101, 70-76.

Maude, A. A Typology of Powerful Geography. Available online: http://www.geocapabilities.org/. (accessed on 04 April, 2019).

Maude, A. Applying the concept of powerful knowledge in school geography. In The Power of Geographical Thinking; Brooks, C., Butt, G., Fargher, M., Eds.; Springer; Cham, Switzerland, 2017; 27-40. 
Mitchell, D.; Lambert, D. Subject knowledge and teacher preparation in English secondary schools: The case of geography. Teach. Dev. 2015, 19, 365-380.

Nussbaum, M.; Sen, A. The Quality of Life. Oxford, UK: University Press. 1993.

OpenStreetMap https://www.openstreetmap.org(accessed on 04 April 2019).

Rediscovering Geography Committee. Rediscovering Geography: New Relevance for Science and Society; National Academy Press: Washington, DC, USA, 1997.

Saatcioglu, M.; Ghobarah, A; Nistor, I. Effects of the December 26, 2004 Sumatra earthquake and tsunami on physical infrastructure. ISET J. Earthq. Technol. 2005, 42, 79-94.

Solem, M; Lambert, D.; Tani, S. Geocapabilities: Towards an international framework for researching the purposes and values of geography education. Rev. Int. Geogr. Educ. Online 2013, 3, 204-219.

Young, M. Bringing Knowledge Back in. Routledge: London, UK, 2008.

Young, M; Muller, J. Three Educational Scenarios for the Future: Lessons from the Sociology of Knowledge. Eur. J. Educ. 2010, 45, 11-27.

Young, M; Lambert, D.; Roberts, C.R.; Roberts, M.D. Knowledge and the Future School: Curriculum and Social Justice; Bloomsbury: London, UK, 2014. 